\title{
Effect of substrate formulations on seedlings of Araucaria angustifolia (Bertol.) Kuntz, a critically endangered species from Southern Brazil
}

\author{
Leandro Marcolino Vieira', Erik Nunes Gomes², Jéssica de Cássia Tomasi', 3 , Valdeci Constantino', 4 , \\ Antônio Carlos Vargas Motta ${ }^{1,5}$, Flávio Zanette ${ }^{1,6}$ \\ ' Universidade Federal do Paraná (UFPR). \\ E-mail: leandro_marcolinovieira@hotmail.com, http://lattes.cnpq.br/I 75988073524I499 \\ ${ }^{2}$ Rutgers University \\ E-mail: e93gomes@gmail.com, http://lattes.cnpq.br//6689820876/4507 \\ ${ }^{3}$ E-mail: jehtomasi@gmail.com, http://lattes.cnpq.br/III759III9425298 \\ ${ }^{4}$ E-mail: deco.constantino@gmail.com, http://lattes.cnpq.br/24I854338I704307 \\ ${ }^{5}$ E-mail: mottaacv@ufpr.br, http://lattes.cnpq.br/8680679653637।38 \\ ${ }^{6}$ E-mail: flazan@ufpr.br, http://lattes.cnpq.br/I848/83975542108
}

\begin{abstract}
Araucaria angustifolia, commonly known as araucária or Paraná Pine, is a critically endangered plant species native to the south of Brazil. Cultivation of this species is an important approach to reduce deforestation while still generating income. The present study aimed to assess the effects of different substrate formulations on araucária seedlings growth, quality and chlorophyll levels in a substrate/container conjugate system, as an approach to promote plant propagation and cultivation. Seeds were sowed in four different substrate compositions: F73 (pine bark, coconut husk fiber, slowrelease fertilizer [SRF] and phosphate fertilizers), F55 (pine bark, coconut husk fiber [in higher proportion $\{20 \%$ more $\}$ than F73], SRF and phosphate fertilizers), T55 (pine bark, Brazilian peat, SRF and phosphate fertilizers) and CC55 (pine bark, sphagnum peat moss, rice straw, SRF and phosphate fertilizers). Seedlings were kept in a nursery area in the substrate/container conjugate system, with manual irrigation. After 180 days from sowing, seedlings were evaluated regarding height, root-collar diameter, leaf and root areas, shoots and roots dry masses and levels of chlorophylls $a, b$ and total chlorophylls. Sturdiness quotient and Dickson quality index (DQI) were also calculated based on the biometric variables. Substrates F73 and CC55 promoted better height and root-collar diameter growth in comparison to other substrates. Other variables related to seedlings growth and quality and chlorophyll levels did not differ according to the substrates. Root and total dry masses were positively correlated with DQI. Root-collar diameter presented high positive correlation with height, shoots dry mass and total dry mass of A.angustifolia seedlings.
\end{abstract}

Keywords: Araucária. Agropote ${ }^{\circledR}$. Substrate/container conjugate system. Dickson quality index. Plant propagation.

\section{Resumo}

Efeito de formulações de substrato em mudas de Araucaria angustifolia (Bertol.) Kuntz, uma espécie do Sul do Brasil criticamente ameaçada de extinção

Araucaria angustifolia, vulgarmente conhecida como araucária ou pinheiro do Paraná, é uma espécie de planta ameaçada de extinção, nativa do sul do Brasil. O cultivo desta espécie é uma abordagem importante para reduzir o desmatamento assegurando a geração de renda. O presente estudo teve como objetivo avaliar os efeitos de diferentes formulações de substrato no crescimento, qualidade e teores de clorofila de mudas de araucária em um sistema conjugado substrato/ 
recipiente, como uma abordagem para promover a propagação e o cultivo da espécie. As sementes foram semeadas em quatro composições diferentes de substrato: F73 (casca de pínus, fibra de casca de coco, fertilizante de liberação lenta [FLL] e fertilizantes fosfatados), F55 (casca de pínus, fibra de casca de coco [em maior proporção $\{20 \%$ a mais $\}$ que em F73], FLL e fertilizantes fosfatados), T55 (casca de pínus, turfa nacional, FLL e fertilizantes fosfatados) e CC55 (casca de pínus, turfa de esfagno, palha de arroz, FLL e fertilizantes fosfatados). As mudas foram mantidas em uma área de viveiro em um sistema conjugado substrato/recipiente, com irrigação manual. Após I 80 dias da semeadura, as mudas foram avaliadas quanto à altura, diâmetro de coleto, áreas foliares e radiculares, massa seca de brotações e raízes e teores de clorofilas $a, b$ e clorofilas totais. O quociente de robustez e o índice de qualidade de Dickson (IQD) também foram calculados com base nas variáveis biométricas. Os substratos F73 e CC55 promoveram maior crescimento de altura e diâmetro de coleto em comparação com outros substratos. Outras variáveis relacionadas ao crescimento e qualidade das mudas e aos níveis de clorofila não diferiram em função dos substratos. A massa seca de raiz e massa seca total foram correlacionadas positivamente com o IQD. O diâmetro do coleto apresentou alta correlação positiva com a altura, a massa seca da parte aérea e a massa seca total das mudas de A.angustifolia.

Palavras-chave: Araucária. Agropote ${ }^{\circledR}$. Sistema conjugado substrato/recipiente de mudas. Índice de qualidade de Dickson. Propagação vegetal.

\section{Introduction}

Araucaria angustifolia (Bertol.) Kuntze (Araucareaceae), commonly known as araucária, Paraná pine or Brazilian pine tree, is a forest tree species native to southern Brazil, with outstanding economic, ecological, social and cultural importance (WENDLING; ZANETTE, 20I7). Originally, the so-called Araucária forest occupied around 196,500 km², representing about a third of southern Brazil surface. However, due to the intense timber exploitation in the past, only I to $2 \%$ of the original area of Araucária forest remains today $(\mathrm{KOCH}$; CORREA, 2002). As a result, A. angustifolia is officially listed as a critically endangered species (IUCN, 20I3).

In view of such problems, the exploitation of araucária pine nuts (pinhões) from commercial cultivation may be a viable alternative for the protection of the species by on-farm conservation approach. The edible seeds of A. angustifolia, commonly referred as pine nuts, are a highly nutritious source of food, rich in carbohydrates, proteins, starch, fibers, calcium, phosphorus, iron and vitamins (FRANCO, 2008). If appropriate management techniques are used, araucária pine nuts can generate more income than timber exploitation and, therefore, can consist of an efficient strategy to both guarantee the generation of resources for rural landowners and to diminish the extractive exploitation of the remaining araucárias (DANNER et al., 20I2).

One of the first steps to introduce A. angustifolia cultivation is the definition of appropriate propagation methods. Although methods of vegetative propagation have been recently studied, araucária propagation is essentially carried out by seedlings, which can be a relatively fast, easy and inexpensive method if some basic aspects of management are taken into consideration (WENDLING; DELGADO, 2008). Among such aspects, the choice of suitable containers and substrates are some of the most important for the production of high quality seedlings.

The so-called substrate/container conjugate system is one of the recent technologies that have been applied for the production of $A$. angustifolia seedlings. In such systems, containers produced with biodegradable fibers are mechanically filled with substrate and subsequently packed in wooden boxes, facilitating the process of sowing and transportation of seedlings. The use of this technology requires the consideration of components that ensure a good aggregation of substrate to the conjugate system while ensuring adequate plant nutrition (WENDLING; ZANETTE, 20I7).

The choice of adequate substrates exerts fundamental influence on the final quality of seedlings, and the use of media that are poor or unbalanced in terms of plant essential nutrients can cause reduced seedling quality (DIAS et al., 2009; ROSSA et al., 20I I). Although some studies have assessed the nutritional aspects of $A$. angustifolia seedlings (ROSSA et al., 20II; CONSTANTINO et al., 20I8), no studies have been found to address the effects of different substrates on the growth of araucária seedlings in the substrate/container conjugate system.

Considering the above, the aim with the present study was to assess the influence of different substrate formulations in substrate/container conjugate system for the production of araucária seedlings. Growth in terms of biomass accumulation, root-collar development, stem elongation and leaf expansion, quality indexes 
and chlorophyll contents as well as the correlation between chemical attributes of substrates and variables related to the initial growth of the species were assessed to demonstrate the overall influence of substrates on A. angustifolia seedling development.

\section{Material and Methods}

The present study was conducted in a nursery located in the city of Curitiba, southern Brazil, at the following coordinates: $25^{\circ} 25^{\prime} 40^{\prime \prime} \mathrm{S}, 4^{\circ} 16^{\prime} 23^{\prime \prime} \mathrm{W}$, and $934 \mathrm{~m}$ altitude ASL. Four commercial substrate formulations for substrate/container conjugate system were tested on A. angustifolia seedlings (F73, F55, T55, CC55). The constituents of each substrate are presented in table I.

Table I. Composition of substrates in substrate/container conjugate system used for the production of Araucaria angustifolia seedlings. Curitiba, Brazil, 2016.

\begin{tabular}{|c|c|}
\hline Substrate & Composition \\
\hline F73 & $\begin{array}{l}\text { Biostabilized compost pine bark; coconut husk fiber; controlled-release fertilizer Osmocote }{ }^{\circledR} \text { Plus I5-09- } \\
\text { I } 2 \text { (nutrients release during 5-6 months); Yoorin }{ }^{\circledR} \text { Master fertilizer and single superphosphate. }\end{array}$ \\
\hline F55 & $\begin{array}{l}\text { Biostabilized compost pine bark; coconut husk fiber (in higher proportion [ } 20 \% \text { more] than substrate } \\
\text { F73; controlled-release fertilizer Osmocote }{ }^{\circledR} \text { Plus I5-09- I } 2 \text { (nutrients release during 5-6 months); Yoorin }{ }^{\circledR} \\
\text { Master fertilizer and single superphosphate. }\end{array}$ \\
\hline T55 & $\begin{array}{l}\text { Biostabilized compost pine bark; Brazilian peat; controlled-release fertilizer Osmocote }{ }^{\circledR} \text { Plus } 15-09-12 \\
\text { (nutrients release during 5-6 months); Yoorin }{ }^{\circledR} \text { Master fertilizer and single superphosphate. }\end{array}$ \\
\hline CC55 & $\begin{array}{l}\text { Biostabilized compost pine bark; Sphagnum peat moss; rice straw; controlled-release fertilizer Osmocote }{ }^{\circledR} \\
\text { Plus I5-09-12 (nutrients release during 5-6 months); Yoorin }{ }^{\circledR} \text { Master fertilizer and single superphosphate. }\end{array}$ \\
\hline
\end{tabular}

Source: Agrofior Produção de Mudas ${ }^{\mathrm{TM}}$, Brazil.

The chemical characteristics of the soil were obtained from the department of Soil Science, Federal University of Paraná. The analyses were based on the methods described by Donagema et al. (20I I).

Table 2. Chemical analysis and density of substrates used for Araucaria angustifolia seedlings production in substrate/container conjugate system. Curitiba, Brazil, 2016.

\begin{tabular}{|c|c|c|c|c|c|c|c|c|c|c|c|c|}
\hline \multirow{2}{*}{ Substrate } & $\mathrm{pH}$ & $\mathbf{A l}^{+3}$ & $\mathbf{H}+\mathbf{A l}$ & $\mathrm{Ca}^{+2}$ & $\mathbf{M g}^{+2}$ & $\mathbf{K}^{+}$ & SB & CEC & $\mathbf{P}$ & C & $\mathbf{V}$ & D \\
\hline & $\mathrm{CaCl}_{2}$ & & --------- & -------c & $\mathrm{mol}_{c} / \mathrm{dm}^{3}$ & ---- & ------- & & $\mathrm{mg} / \mathrm{dm}^{3}$ & $\mathrm{~g} / \mathrm{dm}^{3}$ & $\%$ & $\mathrm{~kg} / \mathrm{m}^{3}$ \\
\hline F73 & 5.4 & 0.0 & 4.6 & 9.7 & 4.6 & 1.4 & 15.7 & 20.3 & 205 & 166.9 & 77.3 & 288.3 \\
\hline F55 & 4.9 & 0.2 & 4.6 & 6.5 & 4.2 & 2.0 & 12.7 & 17.3 & 217 & 141.3 & 73.5 & 188.3 \\
\hline T55 & 4.8 & 0.1 & 12.1 & 15.2 & 4.7 & 0.7 & 20.6 & 32.7 & 135.3 & 252.4 & 63.0 & 324.0 \\
\hline CC55 & 5.2 & 0.2 & 4.6 & 9.3 & 4.8 & 0.9 & 15.0 & 19.6 & 275 & 136.4 & 76.5 & 341.1 \\
\hline
\end{tabular}

SB: sum of bases; CEC: Cation exchange capacity; V: Base saturation percentage; D: density of dry substrate.

The containers used in the experiment were made of nonwoven fabric (TNT) composed of polypropylene fibers, in conic shape with $15 \mathrm{~cm}$ height and volume of $529 \mathrm{~cm}^{3}$ (Agropote ${ }^{\circledR}$, Agrofior Produção de Mudas ${ }^{\mathrm{TM}}$, Brazil). The containers were mechanically filled with the different substrate formulations and subsequently packed in wooden boxes in groups of 40 containers (Figures Ia and Ib).

Araucária seeds were collected from five trees with approximately 20 meters in height, located in the City of Curitiba, Paraná State, Brazil. The seeds were submerged in water for 24 hours and subsequently sowed in the containers with different substrates. The sowing procedure was performed as described by Wendling and Delgado (2008), using one seed per container and deepening two thirds of the seed length in the substrate, keeping the hilum covered and the seed slightly tilted (Figure I a). 
Sowing took place in August 2016 and the plants were evaluated at 189 days after sowing, in February, 2017. A summary of the weather conditions in the nursery during the experiment conduction is presented in table 3. Irrigation was carried out manually, every other day up until substrate saturation. Weeds were controlled manually as needed.

Table 3. Weather conditions during the growth of $A$. angustifolia seedlings in different substrate formulations in substrate/container conjugate system. Curitiba, Brazil, 2016.

\begin{tabular}{llllllll}
\hline Variables & Aug/2016 & Sep/2016 & Oct/2016 & Nov/2016 & Dec/2016 & Jan/2017 & Feb/2017 \\
\hline Precipitation $(\mathrm{mm})$ & 172.3 & 95.0 & 172.1 & 102.7 & 76 & 191.2 & 86.7 \\
Relative humidity $(\%)$ & 79.5 & 75.7 & 82.9 & 79.8 & 77.2 & 80.5 & 76.8 \\
Mean maximum Temperature $\left({ }^{\circ} \mathrm{C}\right)$ & 21.3 & 22.4 & 22.7 & 24.5 & 26.4 & 28.0 & 29.2 \\
Mean minimum Temperature $\left({ }^{\circ} \mathrm{C}\right)$ & 10.6 & 11.4 & 13.8 & 15.0 & 17.5 & 18.7 & 18.8 \\
Mean temperature $\left({ }^{\circ} \mathrm{C}\right)$ & 14.8 & 15.5 & 17.1 & 18.6 & 21.2 & 22.0 & 22.8 \\
\hline
\end{tabular}

Source: National Institute of Meteorology (INMET), 2017.

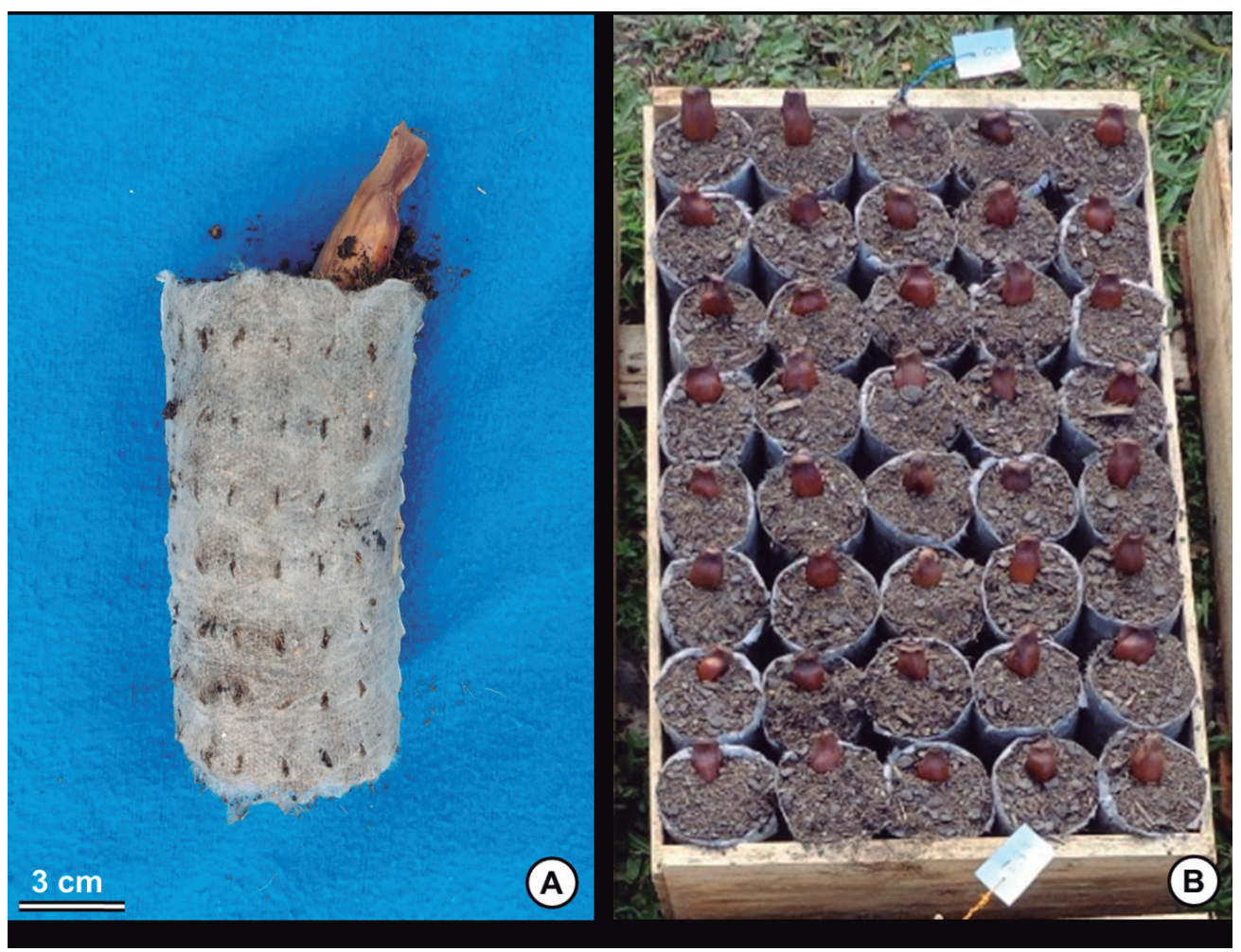

Figure I.

Araucaria angustifolia seeds sowed in substrate/ container conjugate system. A: Agropote ${ }^{\circledR}$ biodegradable container made of nonwoven fabric (TNT). Note A. angustifolia seed slightly tilted as part of the sowing technique B: pack of 40 Agropote ${ }^{\circledR}$ substrate/ container conjugate systems in wooden box.

After first emergence (63 days), seedlings height was measured every 21 days, totaling 7 periods of height evaluation up to the end of the experiment. At 189 days from sowing (Figure 2), the seedlings were evaluated regarding final aboveground height $(\mathrm{cm})$ and root collar diameter $(\mathrm{mm})$. Afterwards, about I $g$ of fresh leaves from the middle third of seedlings was collected, frozen in liquid nitrogen and stored at $-20{ }^{\circ} \mathrm{C}$ until chlorophyll analyses were performed. Stems, leaves and roots were manually separated and the fresh leaves and roots were analyzed in an optical scanner coupled to the software WinRHIZO Pro v. 2002c (Régent Instruments Inc. 2004) to determine the leaf and root areas. After scanning, shoots and roots were dried at $65^{\circ} \mathrm{C}$ to the determination of shoot dry mass, roots dry mass and total dry mass. Based on the biometric variables, sturdiness quotient $-H / C D$ (aboveground height/root collar diameter ratio), and Dickson quality index - DQI (DICKSON et al., 1960) were calculated.

Chlorophylls $a$ and $b$ and total chlorophyll contents were determined by macerating $0.5 \mathrm{~g}$ of frozen araucária leaves in a mortar with $10 \mathrm{ml}$ of $80 \%$ acetone. Subsequently, the solution was placed in test tubes 
wrapped in aluminum foil and centrifuged for 10 minutes at $12,000 \mathrm{rpm}$ and $4{ }^{\circ} \mathrm{C}$. An aliquot $(\mathrm{I} \mathrm{ml})$ of the supernatants was then transferred to quartz cuvettes and the absorbance of the solutions was measured at 645 and $663 \mathrm{~nm}$ using a UVI60I Shimadzu spectrophotometer. The control consisted of $80 \%$ acetone. The quantification of chlorophylls was performed according to the equations described by Arnon (1949) and the results were expressed in milligrams of chlorophyll per gram of fresh leaves $\left(\mathrm{mg} \mathrm{g}^{-1}\right)$.

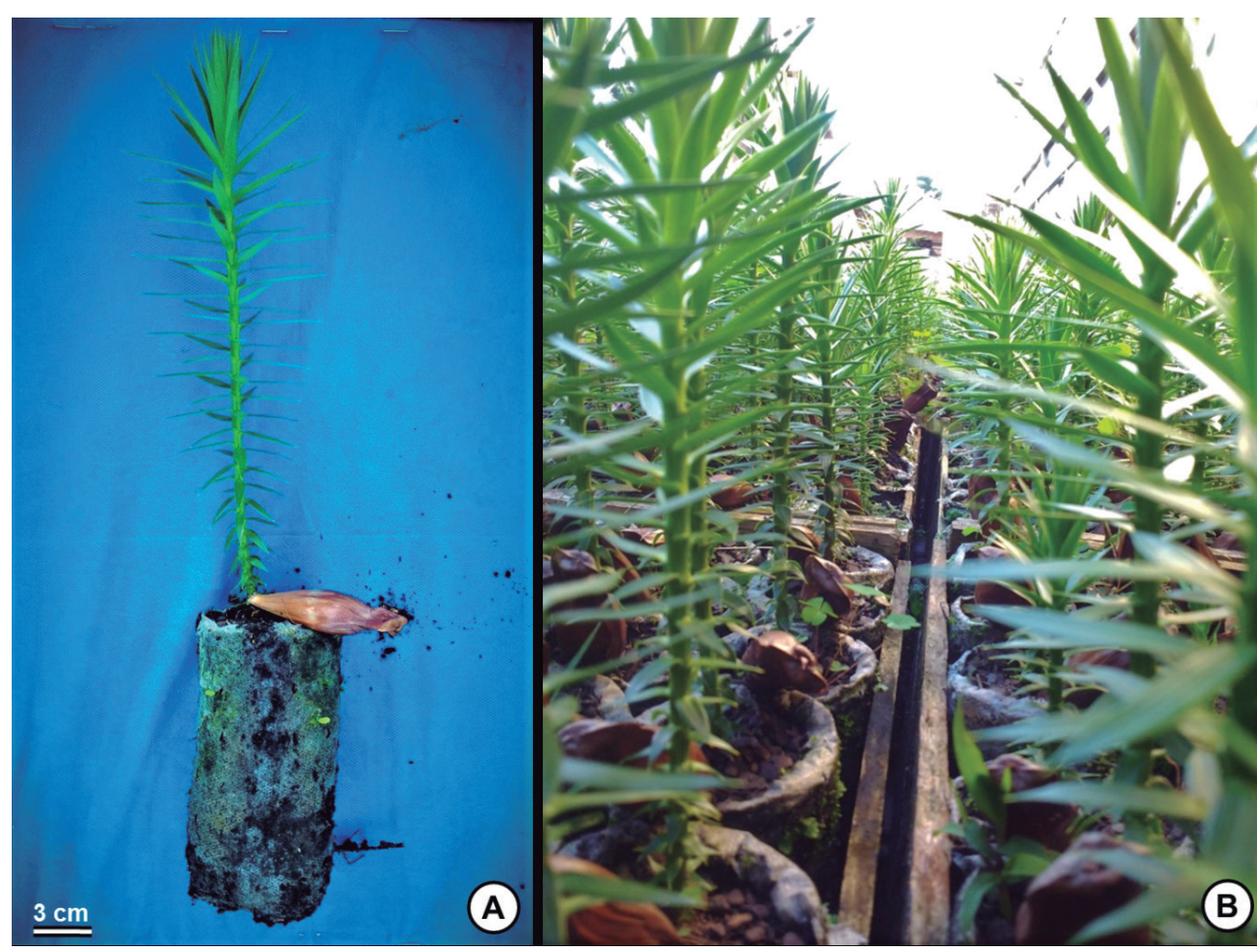

Figure 2.

Araucaria angustifolia seedlings at 189 days from sowing. A: Detail of $A$. angustifolia seedling in biodegradable nonwoven fabric (TNT) container. B: overall aspect of $A$. angustifolia seedlings grown in substrate/container conjugate system.

The experiment was conducted in a completely randomized design, with 4 treatments, 5 repetitions and 40 plants per plot. For the aboveground height, a split-plot in time error-control structure was utilized, with 4 treatments (substrates) as plots and 7 time points as subplots.

Data were submitted to Bartlett's test for homogeneity of variances and Analysis of Variance (ANOVA) was applied when the assumptions were met. When significant, the means were compared by the Tukey's test. Pearson correlation coefficients were established among the assessed variables. Assistat ${ }^{\circledR}$ statistical software (SILVA; AZEVEDO, 2016) was used to perform the analyses.

\section{Results and Discussion}

Substrates $\mathrm{F} 73$ and CC55 provided better growth in height of $A$. angustifolia seedlings, on average $3.1 \mathrm{~cm}$ taller than seedlings produced on substrates F55 and T55 (Table 4). For root-collar diameter, substrates F73 and CC55 promoted higher values than T55. The other variables were not significantly influenced by the substrates at 189 days (Table 4).

Differences on seedling's height started to be noticed at 147 days from sowing, when F73 and CC55 promoted better growth (Figure 2). Agronomically, seedling height is an important variable to indicate the time of transplanting to the field (JOSÉ et al., 2009), being widely used because of its easy assessment and non-destructive nature (GOMES et al., 2002). Height is an especially important feature when seedlings need to be transplanted in weed-infested areas, where vertical growth leads to greater ability to compete for light (ROSSA et al., 20I5). As Paraná pines grow better in low tree density environments (LONGHI et al., 20I0) or in high light conditions, the use of substrates that promote higher seedling height is a fundamental characteristic for this species propagation.

According to Wendling and Delgado (2008), A. angustifolia seedlings produced in polypropylene conetainers will be suitable for field transplanting in 4 to 8 months, with heights between 15 and $30 \mathrm{~cm}$, varying according to the container size $\left(110-210 \mathrm{~cm}^{3}\right)$. Similar quality standards for height were obtained at 189 
days in the present study with $529 \mathrm{~cm}^{3}$ container size (Table 4, Figure 2). These height values are also similar to those reported by Rossa et al. (201 I), when growing araucária seedlings in substrates treated with slowrelease fertilizers and with $180 \mathrm{~cm}^{3}$ container size, with growth up to $34.0 \mathrm{~cm}$ at 190 days.

Table 4 - Variables associated with growth and quality of Araucaria angustifolia seedlings produced in substrate/container conjugate system with different substrate compositions at 189 days of sowing (Curitiba / Brazil - 2017).

\begin{tabular}{|c|c|c|c|c|c|c|c|c|c|c|c|c|}
\hline \multicolumn{13}{|c|}{ Variables } \\
\hline \multirow{2}{*}{ Substrate } & $\mathbf{H}$ & CD & H/CD & RDM & SDM & TDM & DQI & LA & RA & CA & CB & $\mathbf{C T}$ \\
\hline & $\mathrm{cm}$ & $\mathrm{mm}$ & & \multicolumn{4}{|c|}{-------------------(g)----------------- } & \multicolumn{2}{|c|}{-----( $\left(\mathrm{cm}^{2}\right)$------ } & \multicolumn{3}{|c|}{-------(mg g $\left.{ }^{-1}\right)-----$} \\
\hline F73 & $33.8 \mathrm{a}$ & $5.0 \mathrm{a}$ & 6.8 & 1.0 & 4.4 & 5.4 & 0.5 & 466.3 & 85.4 & 0.9 & 0.5 & 1.4 \\
\hline F55 & $31.6 \mathrm{~b}$ & $4.8 \mathrm{ab}$ & 6.6 & 0.9 & 3.7 & 4.6 & 0.4 & 405.9 & 78.8 & 0.7 & 0.4 & I.I \\
\hline T55 & $30.8 \mathrm{~b}$ & $4.7 \mathrm{~b}$ & 6.5 & 0.8 & 3.5 & 4.3 & 0.4 & 409.9 & 66.7 & 0.8 & 0.5 & 1.3 \\
\hline CC55 & $34.8 \mathrm{a}$ & $5.0 \mathrm{a}$ & 7.0 & 0.9 & 4.3 & 5.2 & 0.5 & 424.3 & 79.0 & 0.9 & 0.6 & 1.5 \\
\hline F-value & $5.7 * *$ & 7.7 *** & $1.2^{\mathrm{ns}}$ & $1.5^{\mathrm{ns}}$ & $2.0^{\text {ns }}$ & $2.0^{\text {ns }}$ & $1.7^{\mathrm{ns}}$ & $1.15^{\mathrm{ns}}$ & $2.3^{n}$ & $0.4^{\mathrm{ns}}$ & $0.4^{\mathrm{ns}}$ & $0.6^{\mathrm{ns}}$ \\
\hline C.V. (\%) & 5.4 & 2.4 & 6.1 & 5.7 & 16.9 & 16.1 & 14.9 & 13.5 & 14.9 & 25.9 & 45.9 & 32.3 \\
\hline
\end{tabular}

*Means followed by the same letter in the columns do not differ from each other by the Tukey's test; **: Significant at I\% probability; ns: not significant; $\mathrm{H}$ : height; $C D$ : root-collar diameter; $H / C D$ : sturdiness quotient; RDM: roots dry mass; SDM: shoots dry mass; TDM: total dry mass; DQI: Dickson Quality Index; LA: leaf area; RA: root area; CA: chlorophyll $a$; CB: chlorophyll b; CT: total chlorophylls.

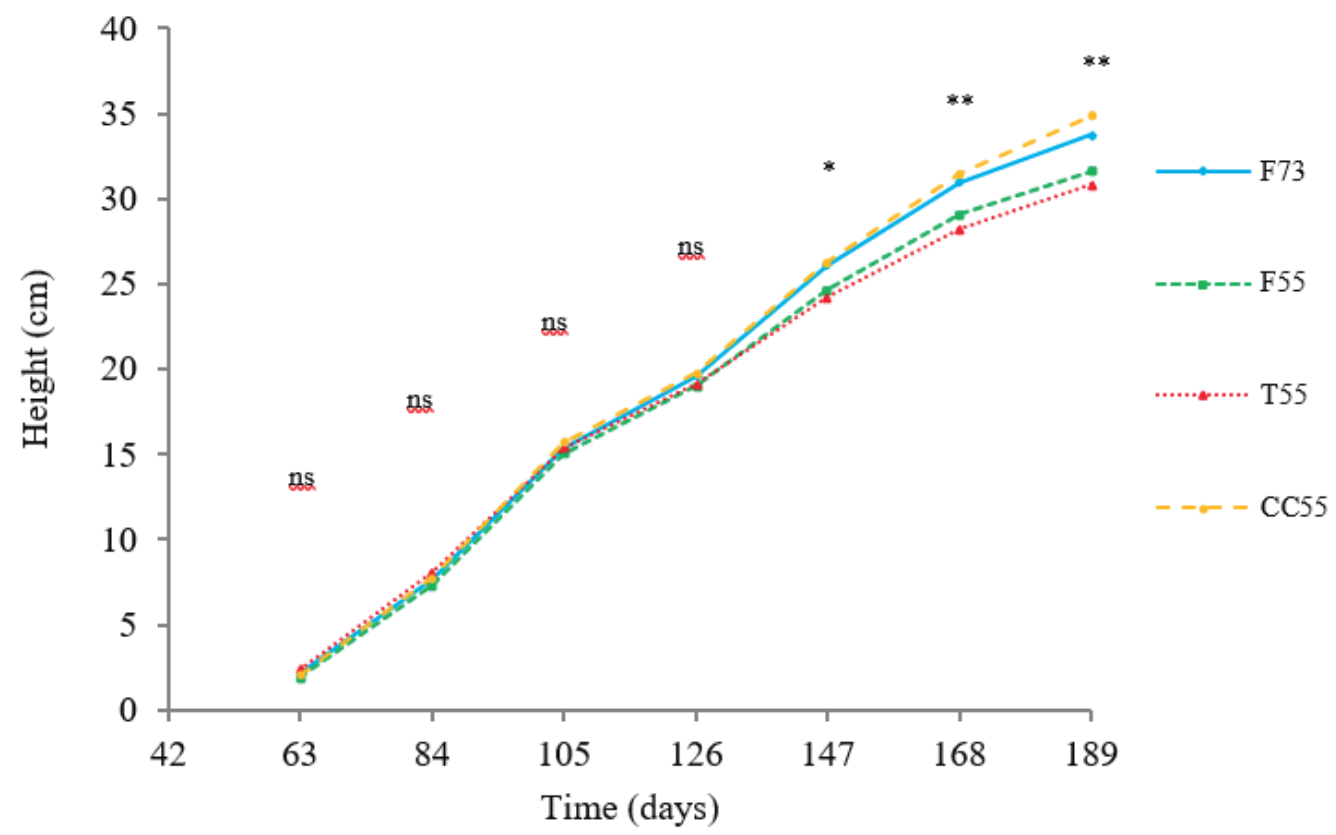

Figure 3.

Height growth of Araucaria angustifolia seedlings produced in substrate/container conjugate system with different substrate compositions (Curitiba/ Brazil - 20I7). ns: not significant;

*: Significant at 5\% probability level; *** significant at $1 \%$ probability level.

Although height is one of the most widely used variables for assessing the quality of forest tree seedlings, the use of this feature alone is not recommended, as excessive growth in height may be an indicator of seedlings etiolation if not accompanied by overall plant the development (ROSSA et al. 20I3). Accordingly, in addition to height, root-collar diameter is a fundamental variable for assessing seedling quality (JOSÉ et al., 2005, BINOTTO et al., 20I0, GOMES et al., 20I3), as well as for prediction of field performance and survival (TSAKALDIMI et al., 20I3). Moreover, root-collar diameter is one of the most important indicators of rootstock quality, considering the diameter requirements for grafting (GOMES et al., 20I0).

Araucária seedlings produced with substrates CC55 and F73 presented higher root-collar diameter than those produced on substrate T55 but did not differ from the substrate F55 (Table 4). The growth in diameter is a function of vascular cambium activity, which is stimulated from carbohydrates produced by photosynthesis and hormones that are translocated from the branches apical regions (KOZLOWSKI, 1962). The stem works as a temporary reservoir of assimilates, which, in later stages of growth, can be translocated and allocated to the leaves to increase the size of the photosynthetic apparatus (LARCHER, 2000). In this sense, it can be observed that the substrates that favored a greater increase in root-collar diameter, had 
higher phosphorus content (Table 2). $\mathrm{P}$ is an essential macronutrient for plant development since it plays important roles in photosynthesis, respiration and energy transfer in the cell (MARSCHNER et al., 20I I), acting as a component of ATP, NADPH and nucleic acid molecules, among other compounds (TAIZ et al., 2017). Increases in height and root-collar diameter were reported by Constantino et al. (2018) on araucária seedlings in response to $\mathrm{P}$, corroborating the results obtained in the present study.

However, it can be inferred that other characteristics of the substrates besides $\mathrm{P}$ contribute to the development of araucária seedlings. One of these characteristics is the base saturation levels (V\%), which was higher on $\mathrm{F} 73$ and $\mathrm{CC} 55$ when compared to the other substrates. Base saturation is an important indicator of soil fertility since high levels of $\mathrm{V} \%$ suggest high concentration of cations, such as $\mathrm{Ca}^{2}{ }^{+}, \mathrm{Mg}^{2+}$ and $\mathrm{K}^{+}$, and decreased levels of $\mathrm{H}^{+}$and exchangeable $\mathrm{Al}^{3+}$ (GORSKI et al., 2019), denoting a suitable environment for plant growth. Similarly to the present study, Vieira and Weber (2017) found that base saturation at $70 \%$ allowed for better development of Tabebuia serratifolia seedlings in comparison to lower levels. Conversely, for Toona ciliata var. australis, Braga et al. (2015) reported that the ideal base saturation was around $50 \%$. Given such differences observed among species, it is important to emphasize the need for specific studies on $A$. angustifolia aiming to determine ideal values of base saturation for substrates used on its propagation.

No differences were observed for the sturdiness quotient of A. angustifolia seedlings (Table 4). It is possible to infer that all substrates promoted adequate values of sturdiness quotients in the present study according to the values established by Hunt (1990). This author established that coniferous seedlings must have a height/root-collar diameter ratio below 10 , since higher values imply seedling etiolation and lower survival rates in the field after transplanting (HUNT, 1990). The work from Hunt (1990) is the closest reference value for $A$. angustifolia seedlings regarding sturdiness quotients and therefore future studies are needed to establish reference values for the species, since specific morphological data need to be taken in account for more precise estimations. The sturdiness quotient expresses seedling growth balance and is an important index for assessing the quality of forest seedlings, as it reflects the accumulation of reserves and the ability of a plant to cope with water deficit and to be efficiently fixed in the soil (ABREU et al., 20I5).

Morphological characteristics are often used to determine seedling quality standards. Height and rootcollar diameter are two of the most important non-destructive evaluations to predict seedling performance after transplanting (GOMES et al., 2002). These two variables presented a positive correlation in araucária seedlings $(r=0.96 \mathrm{I} ; \mathrm{p}<0.05)$ (Table 5). Root-collar diameter also showed positive correlations with seedlings shoots dry mass and total dry mass (Table 5), evidencing the relationship between collar diameter and net photosynthesis and, consequently, biomass accumulation.

Table 5. Pearson's correlation coefficients among growth, quality and chlorophyll contents of Araucaria angustifolia seedlings and chemical attributes of substrates used in substrate/container conjugate system with different substrate compositions at 189 days of sowing (Curitiba / Brazil - 2017).

\begin{tabular}{lccccccccc}
\hline & $\mathrm{H}$ & $\mathrm{CD}$ & $\mathrm{RDM}$ & $\mathrm{SDM}$ & $\mathrm{TDM}$ & $\mathrm{DQI}$ & $\mathrm{RA}$ & $\mathrm{CA}$ & $\mathrm{CB}$ \\
\hline $\mathrm{H}$ & $\mathrm{I}$ & & & & & & & & \\
$\mathrm{CD}$ & $0.96 *$ & $\mathrm{I}$ & & & & & & & \\
$\mathrm{RDM}$ & $n s$ & $n s$ & $\mathrm{I}$ & & & & & & \\
$\mathrm{SDM}$ & $n s$ & $0.99 * *$ & $0.96 *$ & $\mathrm{I}$ & & & & & \\
TDM & $n s$ & $0.99 * *$ & $0.98 *$ & $0.99 * *$ & $\mathrm{I}$ & & & & \\
$\mathrm{DQ}$ & $n s$ & $n s$ & $0.99 * *$ & $n s$ & $0.96 *$ & $\mathrm{I}$ & & & \\
RA & $n s$ & $n s$ & $n s$ & $n s$ & $n s$ & $n s$ & $\mathrm{I}$ & & \\
CA & $n s$ & $n s$ & $n s$ & $n s$ & $n s$ & $n s$ & $n s$ & I & \\
CB & $n s$ & $n s$ & $n s$ & $n s$ & $n s$ & $n s$ & $n s$ & $0.99 * *$ & I \\
\hline
\end{tabular}

***: Significant at I\% probability; * Significant at $5 \%$ probability; ns: not significant; H: height; CD: root-collar diameter; RDM: roots dry mass; SDM: shoots dry mass; TDM: total dry mass; DQI: Dickson Quality Index; RA: root area; CA: chlorophyll $a$; CB: chlorophyll $b$.

The substrates studied in the present study did not promote any difference on seedlings shoot, roots and total biomass. Possibly, araucária seedlings produced in the substrate-container conjugate system require a longer period of development for further evaluation of the effects of the substrate, considering the relatively high volume of the container $\left(529 \mathrm{~cm}^{3}\right)$. 
In the present study, the Dickson quality indexes (DQI) of araucária seedlings did not differ according to the substrates, ranging from 0.4 to 0.5 (Table 4). Given the different biometric variables used to assess the effect of substrates on seedlings growth, it is necessary to observe the set of relationships among these responses to estimate seedlings overall quality. The DQI is a tool that is widely used for this purpose (ROSSA et al., 20I I; ALMEIDA et al., 20I8; CAVALCANTE et al., 20l9). This index estimates the robustness and equilibrium of the distribution of seedling biomass, connecting the results of several variables for quality assessment (FONSECA et al., 2002). DQI values in the present study were at least twice higher than the minimum recommended by Hunt (1990) for seedlings of coniferous species, such as A. angustifolia. The DQl's obtained in the present study are also similar to those reported by Schorn et al. (20I9) on araucária seedlings grown in $200 \mathrm{~cm}^{3}$ containers (DQI=0.535). However, we emphasize that DQI values vary according to the species and environmental conditions, therefore specific morphological components for A. angustifolia still need to be studied in order to determine ideal $\mathrm{DQI}$ indexes for the species.

The DQl's of araucária seedlings showed a positive correlation with shoots dry mass and total dry mass, corroborating the results reported by Binotto et al. (2010) on Eucalyptus grandis and Pinus elliottii seedlings. These authors pointed out that the dry mass variables were the most strongly related to DQI in both species and, thus, were the most reliable to estimate seedling quality (BINOTTO et al., 20I0). It is worth it to mention that ideal DQI values for $A$. angustifolia are not found in the scientific literature, and, therefore, research is still needed to correlate the quality indexes with the performance of the seedlings after transplanting to establish minimum DQI values for the species.

There were no significant differences caused by the treatments in neither leaf nor roots area (Table 4). Leaf area is an important variable to assess seedling quality as it represents the ability of a plant to intercept light and convert it to chemical energy and, ultimately, growth (FAVARIN et al., 2002). Therefore, a larger leaf area usually implies a greater light harvesting capacity, which may result in higher photosynthetic rates (PARTELLI et al., 2006). The root area, in turn, represents the contact area between the root system and the soil and, according to Tsakaldimi et al. (20I3), root area is positively correlated with the survival of seedlings in the field after transplanting.

Regarding the levels of chlorophylls $a, b$ and total chlorophylls in araucária leaves, no differences were observed to be caused by the substrates. Possibly, this behavior is due to the fact that the studied substrates contain similar Mg contents (Table 2). In addition to playing an important role in activating enzymes involved in photosynthesis, respiration, and DNA and RNA synthesis, magnesium is also a structural constituent in the chlorophyll molecule (CAKMAK; YAZICI, 20I0; TAIZ et al., 20I7).

It is noteworthy that the nutritional requirements of seedlings and adult plants can be different and few studies have been carried out in this regard on A. angustifolia (CONSTANTINO et al., 20 I8). Further studies on Araucária propagation are still required to optimize the production process and reduce costs.

\section{Conclusions}

The substrates F73 and CC55 promote the greatest seedling height on Araucaria angustifolia and are also superior to TC55 for root-collar diameter. Other variables related to seedling growth, quality and chlorophyll contents do not differ according to the different tested substrates in substrate/container conjugate system. Root and total dry masses are positively correlated with DQI in the species. Rootcollar diameter presents high positive correlation with height, shoots dry mass and total dry mass of A.angustifolia seedlings.

\section{Acknowledgments}

The authors acknowledge the funding received from the Brazilian Federal Agency for Support and Evaluation of Graduate Education (CAPES) - Finance Code 00I for the first author and DOC_PLENO/ proc. $\mathrm{n}^{\circ}$ 8888I.I29327/2016-0I for the second author. The authors would like to thank the company Agrofior Produção de Mudas ${ }^{\mathrm{TM}}$, Brazil for the supply of the substrate/container conjugate system. 


\section{References}

ABREU, A. J. M. et al. Produção de mudas e crescimento inicial em campo de Enterolobium contortisiliquum produzidas em diferentes recipientes. Floresta, 45, I4I-I50, 2015.

ALMEIDA, U. O. de et al. Environment and slow-release fertilizer in the production of Euterpe precatoria seedlings. Pesquisa Agropecuária Tropical, v. 48, n. 4, p. 382-389, 2018.

ARNON, D. I. Copper enzymes in isolated chloroplasts. Polyphenoloxidase in Beta vulgaris. Plant physiology, v. 24, n. I, p. I, 1949.

BINOTTO, A. F. et al. Correlations between growth variables and the Dickson quality índex in forest seedlings. Cerne, v.16, n.4, p.457-464, 2010.

BOENE, H. C. A. M. et al. Efeitos de diferentes substratos na produção de mudas de Sebastiania commersoniana. Floresta, v. 43, n. 3, p. 407-420, 2013.

BRAGA, M. M. et al. Influência da saturação por bases na qualidade e crescimento de mudas de cedro-australiano (Yoona ciliata M. Roem var. australis). Ciência Florestal, Santa Maria-RS, v. 25, n. I, 20 I 5.

CAKMAK, I.; YAZICI, A. M. Magnesium: a forgotten element in crop production. Better crops, v. 94, n. 2, p. 23-25, 2010.

CAVALCANTE, A. G., et al. Growth and nutrition of Pitombeira (Tasilia esculenta Radlk) seedlings in different substrates and biofertilizer application. Australian Journal of Crop Science, v. I3, n. I, p. 105- I I4, 2019.

CONSTANTINO, V. et al. Initial growth of Araucaria angustifolia rootstock in response to fertilization with nitrogen, phosphorus and potassium. Floresta, v. 49, n. I, p. 99-108, 2018.

DANNER, M. A. et al. O cultivo da araucária para produção de pinhões como ferramenta para a conservação. Pesquisa Florestal Brasileira, v. 32, n. 72, p. 44I-45I, 2012.

DIAS, T. J. et al. Desenvolvimento e qualidade nutricional de mudas de mangabeiras cultivadas em substratos contendo fibra de coco e adubação fosfatada. Revista Brasileira De Fruticultura, v. 3I, n. 2, p. 5I 2-523, 2009.

DICKSON, A. et al. Quality appraisal of white spruce and white pine seedling stock in nurseries. The Forestry Chronicle, n. 36, n. I, p. 10-13, 1960.

DONAGEMA, G. K. et al. Manual de métodos de análise de solo. 2. ed. Rio de Janeiro: EMBRAPA Solos, 201 I.

FAVARIN, J. L. et al. Equações para a estimativa do índice de área foliar do cafeeiro. Pesquisa

Agropecuária Brasileira, v.37, n.6, p.769-773, 2002.

FONSECA, É. D. P. et al. Padrão de qualidade de mudas de Trema micrantha (L.) Blume, produzidas sob diferentes períodos de sombreamento. Revista árvore, v.26, n.4. p. 5I5-523, 2002.

FREITAS, S. J. et al. Substratos e Osmocote ${ }^{\circledR}$ na nutrição e desenvolvimento de mudas micropropagadas de abacaxizeiro cv. vitória. Revista Brasileira de Fruticultura, v. 33, n. spe I, p. 672-679, 20 II.

FRANCO, G. Tabela de composição química dos alimentos. 9 ed. São Paulo: Atheneu, 2008.

GOMES, J. M. et al. Parâmetros morfológicos na avaliação da qualidade de mudas de Eucalyptus grandis. Revista Árvore, v. 26, n. 6, p.655-664, 2002.

GOMES, D. R. et al. Lodo de esgoto como substrato para produção de mudas de Tectona grandis L. Cerne, v. I9, n.I I23-131, 2013.

GOMES, W. D. A. U et al. Garfagem e diâmetro de porta-enxerto na obtenção de mudas de umbuzeiro do acesso laranja. Revista Brasileira de Fruticultura, v. 32, n. 3, p. 952-959, 2010.

GORSKI, M. R. et al. Variabilidade espacial da saturação por bases e da saturação por alumínio do solo, numa catena do pampa, cultivada com soja. Brazilian Journal of Development, v. 5, n. 5, p. 3660-3667, 2019.

HUNT, G. A. Effect of styroblock design and cooper treatment on morphology of conifer seedlings. In: Target Seedling Symposium, Meeting Of The Western Forest Nursery Associations, General Technical Report RM-200, 1990, Roseburg. Proceedings... Fort Collins: United States Departament of Agriculture, Forest Service, 1990. p. 2 I 8-222. 
INTERNATIONAL UNION FOR CONSERVATION OF NATURE AND NATURAL RESOURCES- IUCN. The Iucn Red List Of Threatened Species: Araucaria Angustifolia (Published In 2013). Disponível Em: <Http://Dx.Doi. Org/I0.2305/lucn.Uk.20I3-I.RIts.T32975a2829I4I.En> Acesso Em: I3 Mai. 2019.

JOSÉ, A. C. et al. Produção de mudas de aroeira Schinus terebinthifolia Radd para recuperação de áreas degradadas pela mineração de bauxita. Cerne, v.II, n.2, p.187-203, 2005.

JOSÉ, A. C. et al. Efeito do volume do tubete, tipo e dosagem de adubo na produção de mudas de aroeira (Schinus terebinthifolia Raddi). Agrarian, v. 2, n. 3, p. 73-86, 2009.

KOCK, Z.; CORRÊA, M. C. Araucária: a floresta do Brasil meridional. Curitiba: Olhar Brasileiro, 2002.

KOZLOWSKI, T. T. Tree Growth. New York: The Ronald Press Company, 1962.

LARCHER, W. Ecofisiologia Vegetal. São Carlos: RiMA Artes e textos, 2000.

LONGHI, S. J. et al. Fatores ecológicos determinantes na ocorrência de Araucaria angustifolia e Podocarpus lambertii, na Floresta Ombrófila Mista da FLONA de São Francisco de Paula, RS, Brasil. Ciência Rural, v. 40, n. I, p. 57-63, 20I0.

MARSCHNER, H. Marschner's mineral nutrition of higher plants. Adelaide: Academic press, $20 \mathrm{II}$.

PARTELLI, F.L. et al. Estimativa da área foliar do cafeeiro conilon a partir do comprimento da folha. Revista Ceres, v.53, n. 306, p.204210, 2006.

RÉGENT INSTRUMENTS. Win/MacRHIZO pró v. 2002c. Reference. Régent Instruments Inc., Québec, Canada. 2004. ROSSA, U. B. et al. Fertilizante de liberação lenta no crescimento de mudas de Araucaria angustifolia e Ocotea odorifera. Floresta, v. 4I, n. 3, p. 49I-500, $201 \mathrm{I}$.

ROSSA, U. B. et al. Fertilizante de liberação lenta no desenvolvimento de mudas de Eucalyptus grandis. Floresta, v. 45, n. I, p. 85-96, 2015.

ROSSA, U. B. et al. Fertilizante de liberação lenta no desenvolvimento de mudas de Schinus terebinthifolius e Sebastiania commersoniana. Floresta, v. 43, n. I, p. 93-104, 2013.

SCHORN, L. A. et al. Definição de idades ótimas para expedição de mudas de Araucaria angustifolia (Bertol.) Kuntze (Araucariaceae) em função de sua qualidade e volume de recipientes. Biotemas, v. 32, n. 4, p. 19-27, 2019.

SILVA, F. A. S. E.; AZEVEDO, C. A. V.. The Assistat Software version 7.7 and its use in the analysis of experimental data. African Journal Of Agricultural Research, v. II, n. 39, p. 3733-3740, 2016.

TAIZ, L. et al. Fisiologia e desenvolvimento vegetal. 6.ed. Porto Alegre: Artmed, 2017.

TSAKALDIMI, M. et al. Prediction of planted seedling survival of five Mediterranean species based on initial seedling morphology. New forests, v. 44, n. 3, p. 327-339, 2013.

VIEIRA, C., WEBER O. Saturação por bases no crescimento e na nutrição de mudas de ipê-amarelo. Floresta e Ambiente, v. 24, n. I, p. 02-10, 2017.

WENDling, I.; DElGadO, M. E. Produção de Mudas de Araucária em Tubetes. Comunicado Técnico, 20I, Embrapa Florestas, Colombo, 2008.

WENDLING, I.; ZANETTE, F. Araucária: particularidades, propagação e manejo de plantios. Brasília: Embrapa, 20 I 7. 